\title{
Secondary Chromosome Associations in Uraria picta (Jacq.) DC (Family: Leguminosae)
}

\author{
Arnab Bhattacharya and Animesh K. Datta* \\ Department of Botany, Cytogenetics and Plant Breeding Section, \\ Kalyani University, Kalyani 741235, India
}

Received January 1, 2010; accepted January 20, 2010

\begin{abstract}
Summary The meiocytes of Uraria picta (Jacq.) DC (Family: Leguminosae; Papillionoide; annual medicinal herb) had $n=11$ chromosomes with an average chromosomal association of 0.11 IV +10.29 II +0.98 I per cell at diakinesis and metaphase I. The bivalents formed rods (rods: $1-11 /$ cell, $6.95 \pm 0.22$; rings: $0-9 /$ cell, $3.59 \pm 0.25 /$ cell) mostly at MI with mean chiasma of $14.22 \pm$ 0.24 (8 to 20) per cell. Formation of 11 II in PMCs was predominant (62.71\%). About $11.25 \%$ of the cells had a ring quadrivalent. All AI cells were cytologically balanced (11/11) with an average pollen fertility of $97.58 \%$. A persistant feature in $100 \%$ diakinesis and MI cells was the presence of secondary association of chromosomes and the chromosomes assorted themselves into variable groups of 2 (0.85\%), 3 (5.08\%), 4 (7.63\%), 5 (11.86\%), 6 (42.37\%), 7 (19.49\%), 8 (3.39\%), 9 $(2.54 \%)$ and $11(1.69 \%)$. Out of 52 different chromosomal associations among the group classes, 3 $\mathrm{II}(1)+2 \mathrm{II}(3)+1 \mathrm{II}(2)-16.10 \%$ (6 group class) was most frequent.
\end{abstract}

Key words Basic chromosome number, Meiosis, Secondary association of chromosomes, Uraria picta.

Pairs of bivalents and univalents lying in close proximity but always without any distinct material connections were referred to as secondary associations or secondary pairings of chromosomes (Darlington 1965). Stebbins (1950) considered these associations to be the result of modified chromosome rearrangements such as duplications, interchanges, etc.; while Jelenkovic et al. (1980) attributed it to the mode of heterochromatin distribution in the genome which possibly facilitates the alignment and synapsis of nonhomologus regions. Malgwi et al. (1997) were of the opinion that secondary associations of bivalents may be the outcome of residual pairing potential of those segments that could not achieve normal synapsis at zygotene but were sufficiently identical to attract each other without the formation of chiasmata. Secondary association of chromosomes was first reported by Kuwada (1910) in Oryza sativa followed by Ishikawa (1911) in Dahlia variabilis and since then were often encountered in meiotic processes of plant species in tracing basic chromosome numbers and the polyploidy nature of the species (Riley 1960, Kempanna and Riley 1964, Sharma and Chatterjee 1966, Gupta and Roy 1973, Agarwal 1983, Sengupta and Datta 2002, 2003, Mukherjee and Datta 2005, Iqbal and Datta 2006). The present investigation describes meiotic chromosome behavior documenting secondary chromosome association in Uraria picta (Jacq.) DC (Family: Leguminosae; Papillionoidae), an annual erect herb (also reported to be a woody herbOkusanya et al. 1991, a perennial herb-Anand et al. 1998, Rahman et al. 2007, and a shrub-Gill and Husaini 1986) with immense traditional therapeutic uses (roots/leaves/whole plant) (Allen and Allen 1981, Jain and Defillips 1991, Kirtikar and Basu 1995, Yusuf et al. 1994). From the available literature it seems that only chromosome number $n=11$ (Miege 1962, Bir and Kumari 1977, Gill and Husaini 1982) and $2 n=16$ (Sanjappa and Dasgupta 1977) are reported in the species. Further, Wheeler et al. (1992) and Pridgeon et al. (2003) documented $2 n=20$ and 22 (18 species analyzed),

*Corresponding author, e-mail: dattaanimesh@gmail.com 
and $2 n=20$ (20 species studied) respectively as the chromosome number for the genus Uraria.

\section{Materials and methods}

For studies of meiosis, villous spike like racemes (young inflorescences of $2.0 \mathrm{~cm}$ to $3.0 \mathrm{~cm}$ in length were collected; flowering period ranged from July to September) from 10 randomly selected plants (plants raised in experimental plots of Kalyani University, West Bengal, $22^{\circ} 99^{\prime} \mathrm{N}, 88^{\circ} 45^{\prime} \mathrm{E}$, elevation 48 feet above mean sea level; a seed sample of the species was collected from Medicinal Plant Garden, Narendrapur Ramkrishna Mission, Govt. of West Bengal; voucher specimen deposited in the Herbarium, Botany Department, Kalyani University) were fixed (5:30 AM to 6:30 $\mathrm{AM})$ in Carnoy's fluid for $48 \mathrm{~h}\left(32^{\circ} \mathrm{C} \pm 2{ }^{\circ} \mathrm{C}\right)$. One to 2 drops of $2 \%$ iron alum was added in the fixative for proper staining and at least 1 change was given at an interval of $24 \mathrm{~h}$ in the fixative for removal of precipitates. Pollen and pollen mother cells (PMCs) were assessed from anther squash preparations from suitable sized flower buds in $2 \%$ propionocarmine solution. Fully stained pollen grains were considered fertile. Meiotic data (diakinesis, metaphase I (MI) and anaphase I (AI)) were pooled over the plants and presented in the text. Photomicrographs were taken from temporary squash preparations.

\section{Results and discussion}

PMC squashes showed $n=11$ chromosomes (Figs. 1-8) in all cases. Out of the 8 different associations studied at diakinesis and MI (236 PMCs' estimated), 11 II formations were the most predominant (62.71\%); while the rest were $1 \mathrm{IV}+9$ II $(4.24 \%), 1 \mathrm{IV}+8 \mathrm{II}+2 \mathrm{I}(3.39 \%), 1 \mathrm{IV}+7$ II+4 I (3.39\%), 10 II+2 I (17.80\%), 9 II+4 I (2.54\%), 8 II+6 I (4.14\%) and 7 II+8 I (1.69\%). Average chromosomal association per cell was noted to be $0.11 \mathrm{IV}+10.29 \mathrm{II}+0.98 \mathrm{I}$. About $11.02 \%$ of the meiocytes had a ring quadrivalent. Bivalents showed prevalence of rod (rods: $1-11 /$ cell, $6.95 \pm 0.22$; rings: $0-9 /$ cell, $3.59 \pm 0.25 /$ cell) configuration at MI (222 cells scored) with mean chiasma of $14.22 \pm 0.24$ ( 8 to 20 ) per cell. All AI cells ( 72 cells analyzed) were cytologically (11/11) balanced. The average pollen fertility recorded in the species (1562 pollen grains assessed) was $97.58 \%$. Thus, it seems that presence of a quadrivalent in relatively higher number of meiocytes did not affect the pollen fertility (as far pollen stainability is concerned) due to their regular disjunction at $\mathrm{AI}$.

It is interesting to note that bivalent frequency per cell tended to form variable groups (2-9 and 11) both in diakinesis and MI cells; although univalents and multivalent were also associated in groups with bivalents. All analyzable meiocytes (100.0\%) demonstrated the formation of secondary groups of chromosomes (Figs. 1-8) in the form of 2 (0.85\%), 3 (5.08\%), 4 (7.63\%), 5 (11.86\%), 6 (42.37\%), 7 (19.49\%), 8 (3.39\%), $9(2.54 \%)$ and 11 (1.69\%). In the present investigation a total of 52 different types of associations were recorded among the group classes, of which $3 \mathrm{II}(1)+2$ $\mathrm{II}(3)+1 \mathrm{II}(2)-6$ group class $(16.10 \%), 3 \mathrm{II}(1)+2 \mathrm{II}(2)+1 \mathrm{II}(4)-7$ group (Figs. 6-8) class (7.63\%), $3 \mathrm{II}(2)+2 \mathrm{II}(1)+1 \mathrm{II}(3)-6$ group class $(6.78 \%), 3 \mathrm{II}(2)+1 \mathrm{II}(5)-7$ group class $(5.93 \%)$, $2 \mathrm{II}(5)+1 \mathrm{II}(1)-6$ group class $(4.24 \%)$ and $5 \mathrm{II}(1)+4 \mathrm{II}(1)+2 \mathrm{II}(1)-3$ group class $(4.24 \%)$ were most frequent.

The computation of $\mathrm{X}^{2}$ tests among the different group classes of $U$. picta $\left(\mathrm{X}^{2}=289.02\right.$ at $3 \mathrm{DF}$, $p<0.001)$ revealed heterogeneity, thereby suggesting that chromosome assortments were non random with a preference to 6 group class. Further, cell frequency of 6 group class was significantly higher than expected and it was verified against the pooled frequency of rest of the group classes (observed: 6 group class - 100, rest-136; expected: 6 group class-26.22, rest-209.76, total 236, $\mathrm{X}^{2}=233.56$ at $\left.1 \mathrm{DF}, p<0.001\right)$. Apart from the frequent occurrence of 6 group class a chromosomal group of 7 was also observed in relatively higher frequency. 

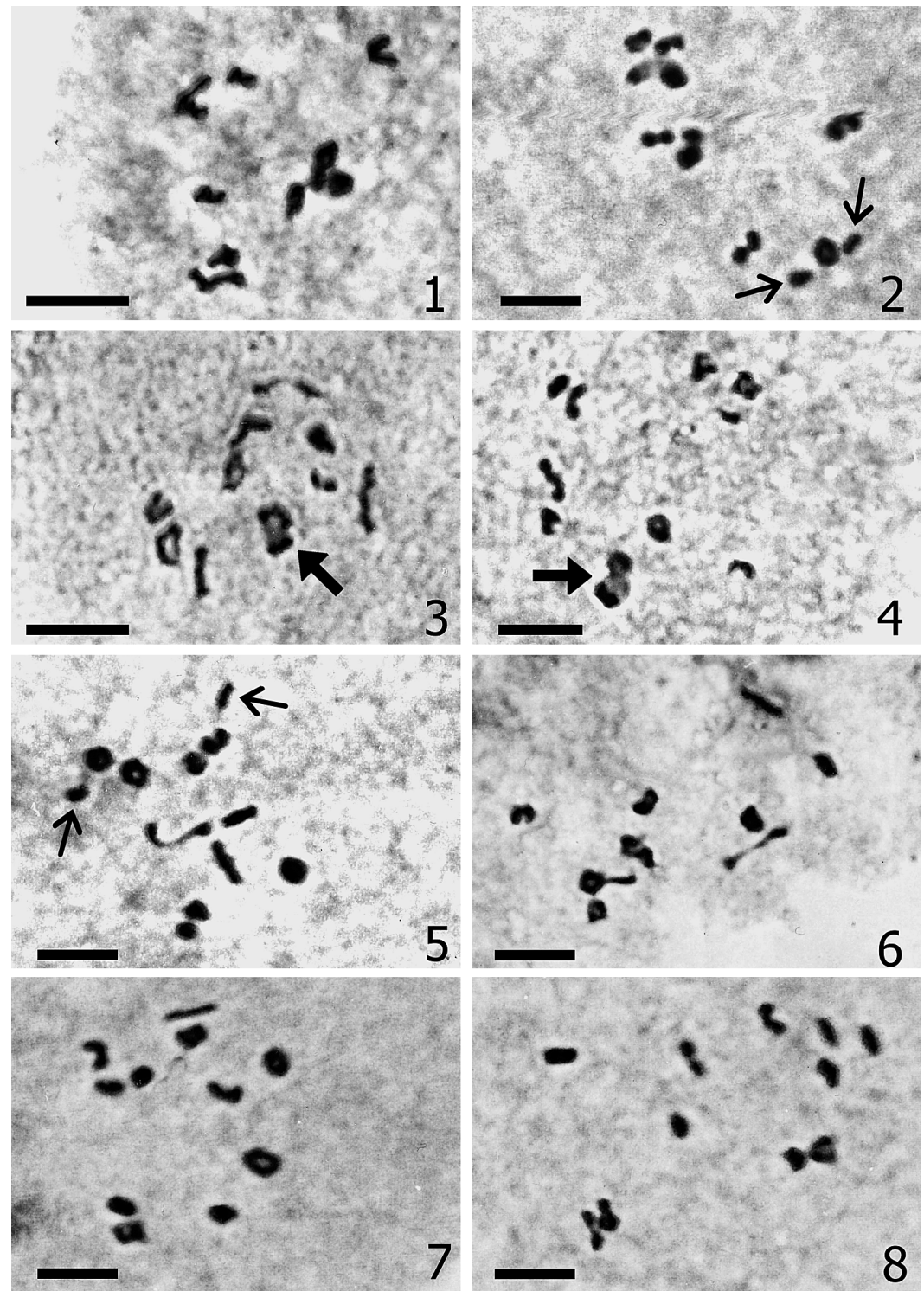

Figs. 1- 8. Metaphase I $(n=11)$ chromosome configurations with secondary groups. $1: 3 \operatorname{II}(3)+1 \operatorname{II}(2)-5$ groups. 2: $4 \mathrm{II}(1)+3 \mathrm{II}(1)+1 \mathrm{II}(2)+1 \mathrm{II}+2 \mathrm{I}(1)-5$ groups. 3-4: $1 \mathrm{IV}(1)+3 \mathrm{II}(1)+2 \mathrm{II}(2)+1$ $\mathrm{II}(2)-6$ groups. $5: 3 \mathrm{II}(1)+2 \mathrm{II}(3)+1 \mathrm{II}(1)+1 \mathrm{I}(2)-7$ groups. 6-8: $3 \mathrm{II}(1)+2 \mathrm{II}(2)+1 \mathrm{II}(4)-7$ groups. Quadrivalent $(\rightarrow)$ and univalents $(\rightarrow$ ) were marked. Scale bar $=10 \mu \mathrm{m}$.

The persistent occurrence of secondary association of chromosomes in U. picta therefore indicates the secondary polyploidy nature of the species and a statistical analysis of cytological data revealed that the probable basic chromosome number is 6 . The species might have undergone cytological diploidization in the course of evolution to show near diploid-like meiotic behavior. Although a variable number of associations were encountered among the group classes, and the preponderance of the quadrivalent formation in relatively large numbers of meiocytes possibly suggests the autopolyploid (probable selective doubling of chromosomes-as $x=6$ and $n=11$ ) lineage of the species. A cytological approach, involving the observation of meiotic cells, is a conventional approach to ascertain whether a species is auto- or allopolyploid in origin (Chenuil et 
al. 1998). However, coupled with meiotic observations, allozyme data or data from Mendelian markers (Olson 1997) and locus specific molecular markers using FISH (Lichter 1997) may give better precision in this regard.

\section{References}

Agarwal, P. K. 1983. Secondary association of bivalents in Cissus discolor blume. Cytologia 48: 577-580.

Allen, O. N. and Allen, K. E. 1981. The Leguminosae. University of Wisconsin Press, Madison pp. 672-673.

Anand, A., Rao, C. R., Latha, R., Josekutty, P. C. and Balakrishna, P. 1998. Micropropagation of Uraria picta, a medicinal plant, through axillary bud culture and callus regeneration. In Vitro Cell. Dev. Biol., Plant 34: 136-140.

Bir, S. S and Kumari, S. 1977. Evolutionary status of Leguminosae from Pachmarhi, Central India. Nucleus 20: 94-98.

Chenuil, A., Galtier, N. and Berreb, P. 1998. A test of hypothesis of an autopolyploid vs. allopolyploid origin for a tetraploid lineage: application to the genus Barbus (Cyprinidae). Heredity 82: 373-380.

Darlington, C. D. 1965. Recent Advances in Cytology (vol. 2). Churchill, London. p. 671.

Gill, L. S. and Husaini, S. W. H. 1982. Cytology of some arborescent Leguminosae of Nigeria. Silvae Genetica 31: 117-122. — and - 1986. Cytological observations in Leguminosae of Southern Nigeria. Willdenowia 15: 521-527.

Gupta, P. P. and Roy, S. K. 1973. Primary and secondary chromosome association in Euryle ferox Salisb. Cytologia 38: 645-649.

Iqbal, M. and Datta, A. K. 2006. Cytogenetic Studies in Withania somnifera (L.) Dun. (Solanaceae). Cytologia 72: $43-47$.

Ishikawa, M. 1911. Cytologische Studien von Dahlien. Bot. Mag. Tokyo 25: 1.

Jain, S. K. and Defillips, R. A. 1991. Medicinal Plants of India. Vol. 1. Reference Publication, Alganao p. 372.

Jelenkovic, G., Shifriss, Q. and Harington, E. 1980. Association and distribution of meiotic chromosomes in a haploid of Ricinus communis L. Cytologia 45: 571-577.

Kempanna, C. and Riley, R. 1964. Secondary association between genetically equal bivalents. Heredity 19: $289-299$.

Kirtikar, K. R. and Basu, B. D. 1995. Indian Medicinal Plants (vol. 1). International Book Distributors, Dehradun. p. 72, $308,562$.

Kuwada, Y. 1910. A cytological study of Oryza sativa L. Bot. Mag. Tokyo 24: 267-281.

Lichter, P. 1997. Multicolour FISHing: What's the catch? Trends Genet. 13: 475-478.

Malgwi, M. M., Oyewole, S. O. and Khan, A. U. 1997. Chromosomes and secondary associations in tetraploid Cleome polyanthera (Linn.). Nucleus 40: 20-25.

Miege, J. 1962. Quatrieme liste de nombres chromosomiques d'especes d'Afrique Occidentale. Rev. Cytol. Biol. Veg. 24: $149-164$.

Mukherjee, M. and Datta, A. K. 2005. Secondary Chromosome Associations in Ocimum basilicum L. and Ocimum tenuiflorum L. Cytologia 70: 149-152.

Okusanya, O. T., Lakanmi, O. O. and Oyesiku, O. O. 1991. Germination ecology of the woody herb Uraria picta, from southern Nigeria. J. Trop. Ecol. 7: 139-146.

Olson, M. 1997. Bayesian procedures for discriminating among hypotheses with discrete distributions: inheritance in the tetraploid Astilbe biternata. Genetics 147: 1933-1942.

Pridgeon, A. M., Cribb, P. J., Chase, M. W. and Rasmussen, F. N. 2003. Genera Orchidacearum. (vol. 1, 2nd ed.) Oxford University Press, Oxford. p. 80.

Rahman, M. M., Gibbons, S. and Gray, A. I. 2007. Isoflavones from Uraria picta and their antimicrobial activity. Phytochemistry 68: 1692-1697.

Riley, R. 1960. The secondary pairing of bivalents with genetically similar chromosomes. Nature 185: 751-752.

Sanjappa, M. and Dasgupta, A. 1977. In: IOPB chromosome number reports LVI. Taxon 26: 257-274.

Sengupta, S. and Datta, A. K. 2002. Secondary association of bivalents in an induced mutant line of sesame (Sesamum indicum L.). J. Phytol. Res. 15: 13-16.

— and - 2003. Secondary Chromosome Associations in Control and Mutant Plant Types of Sesamum indicum L. Cytologia 68: 141-145.

Sharma, A. K. and Chatterjee, A. K. 1966. Cytological studies on orchids with respect to their evolution and affinities. Nucleus 9: 177-203.

Stebbins, G. L. 1950. Variation and Evolution in Plants. Columbia University Press, New York.

Wheeler, J. R., Rye, B. L., Koch, B. L. and Wilson, A. J. H. 1992. Flora of Kimberley Region, J. Botaniq. Journal No.: 1327.

Yusuf, M., Chowdhury, J. U., Wahab, M. A. and Begum, J. 1994. Medicinal Plants of Bangladesh. BCSIR Laboratories, Chittagong, Bangladesh. 